\title{
Durgapur Steelworks project: administration, co-ordination and measurement of the civil engineering and building works
}

\author{
by \\ C. A. Gillott, B.Eng., M.I.C.E., \\ D. R. Tyler, B.Sc., A.M.I.C.E. \\ and \\ J. F. Reeve, A.I.Q.S.
}

Mr J. H. Thornton (English Electric Co. Ltd) wrote that he was interested in the operation of consortia of the type described in the Paper and would be grateful if the Authors could answer a few questions.

78. Was ISCON a company, formed by members of the consortium, and employing its own staff for overall co-ordination of design and construction?

79. If ISCON made a profit or loss what distribution was made to member companies; was there differentiation between 'principal' and 'sub-contractor' companies?

80. In $\S 21$ reference was made to the cost of civil work almost doubling. Was the reason for this extra work required by the Client or additional work called for by the plant companies? Who paid for the increased amount of work?

81. Did ISCON itself have a Site Manager to whom the Civil Engineering Manager was responsible? If there was a Site Manager, what size of staff did he control? What authority did he have over other organizations on the site?

82. In what way did the supervision provided by the Resident Engineer exercise control? What was the relationship of this organization to that of the Chief Engineer (Inspection)? How many personnel were on the staff?

83. In \& 48 reference was made to the extra effort made to adhere to programme without extra cost to the Client. Who did, in fact, carry the extra cost?

84. In the specimen priced bill three items, 39G, 39K, 39P covering concrete class 1500 in foundations exceeding 12 in., walls exceeding 12 in., and floors exceeding 12 in., all had the same rate of 233.5000 rupees. Would there not appear to be a case for having only one rate per cubic yard of concrete with extra rates to cover the additional cost of work below or above ground level, working round reinforcement or pipes and so on ? That is, a basic rate for supplying and transporting a cubic yard of concrete and extra items to cover the differing methods and locations of placing.

85. The rates for grouting-up under base plates, items 3.8.61 and 3.8.63 were not greatly dissimilar if converted to a cubic foot measurement. It appeared that some simplification of measurement could take place, generally, if similarities such as these were taken into account.

Mr Asit K. Biswas (Lecturer, Department of Civil Engineering, University of Strathclyde, Glasgow) wrote that for a major scheme like the Durgapur Steelworks, proper co-ordination between various firms was essential. Having worked at the Durgapur Steelworks Project for some time, the writer was aware of some of the problems.

* Proc. Instn civ. Engrs, vol. 29, November, 1964, pp. 589-608. 
DISCUSSION ON DURGAPUR STEELWORKS PROJECT: ADMINISTRATION,

87. It seemed that there had been a lack of supervision at Durgapur. This could best be illustrated by the fact that the Government of India announced on June 12,1959 that they had withheld a part of the payment due to the Indian Steelworks Construction Company Limited, a consortium of thirteen British companies, the main reason being the defective piling at certain sections of the plant. On the same day the General Manager of the Durgapur Steelworks project made a statement in London that some defects had been noticed under the smelting furnaces 7,8 , and 9 due to inadequate piling. Subsequently the Government of India announced that a committee of engineers had been set up, 'to investigate these defective pile foundations and to reassure the Government that all the pile foundations had been fully tested and properly laid'. After elaborate investigations the Committee suggested that there should be complete dismantling of the piles in certain sections of the plant. Mr Biswas did not have complete details of the terms of reference and final recommendations made by the Committee, and hoped that the Authors would be able to cast some light on the matter.

The Authors thanked Messrs Thornton and Biswas for their questions. In reply to Mr J. H. Thornton they would take each question in turn.

89. ISCON was formed as a company by members of the Consortium, and employed its own staff for overall co-ordination and design. However, most of the detailed co-ordination and design was sub-let to member companies.

90. As the Contractor ISCON was generally responsible for receiving and distributing payments and all charges among the member sub-contractors on bases agreed by the board, upon which the interests of all member sub-contractors were represented. There was no differentiation. All member companies of ISCON were member sub-contractors. Member companies in turn sub-let parts of their works to non-member sub-contractors.

91. The increase in civil engineering and building work resulted from the additional requirements of the Client, the Consulting Engineers, and the plant companies. All work to be done by the Site Works Contractor was subject to the technical and financial agreement of the Consulting Engineer who certified payment to be made by the Client.

92. ISCON had a Resident Director on site who controlled and co-ordinated the work of the member companies. The Civil Engineering Manager of the Site Works Civil Engineering and Building Works Sub-Contractor was responsible for the overall performance of the work of his company within the consortium to the Resident Director (see Fig. 6). The Civil Engineering Manager was responsible to his own company management for the efficient and profitable execution of the work. The Resident Director was responsible for the overall control of all construction work and he represented the Consortium on all affairs which were concerned with Hindustan Steel Limited, the Resident Engineer, and any other outside authorities. The Resident Director made full use of the services and advice of senior representatives of member companies of the consortium on site in contractual and technical matters but ultimately the decision was made by him. At peak the total staff of the Resident Director in India was about 200.

93. All works had to be executed to the satisfaction of, and all drawings had to be approved by, the Engineer or his representatives. In general the Engineer, on behalf of the Client, supervised the works in the conventional way-he approved works and certified and valued them, issued interim certificates of valuation, etc. The Authors regretted that they had no records of the numerical strength of the Resident Engineer's staff, the majority of whom were seconded from the service of the Client. Whilst the Chief Engineer (Inspection) carried out as imilar function to that of the Resident Engineer, he did so on behalf of the member sub-contractor, Cementation, in respect of the work executed as a sub-contract by Cementation-Patel, 


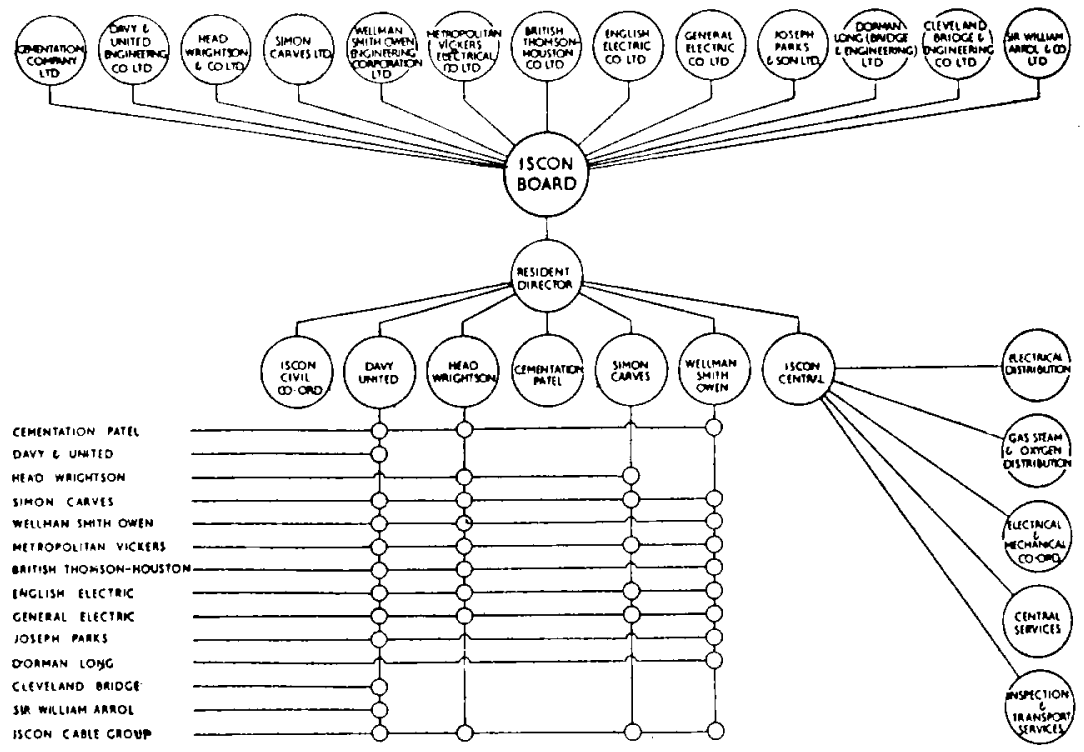

[By permission of Iron \& Coal Trades Review

Fig. 6: Chart SHOWING ORGANIZATION OF ISCON

the joint venture responsible for the work at site. However, the Chief Engineer (Inspection) represented the member sub-contractor when dealing with technical matters with the Resident Engineer.

94. The cost of the extra effort made to adhere to the original programme was carried by the site works sub-contractor.

95. The intention of the specimen priced bill was to demonstrate the method adopted. Any similarity in the pricing should, therefore, be ignored. The principle of working from a basic item was adopted so far as was considered reasonable. In Mr Thornton's example, instead of measuring the items 39G, 39K, and 39P one would measure (Item 1) supply and transport Class 1500 Concrete, (Item 2) handle and Place concrete in foundations, walls or floors exceeding 12 in. thick. Having saved one item, one had then increased the number of measurements to be recorded, for the measurements previously allocated among three items had now to be recorded against (Item 1) and duplicated against (Item 2). On a smaller contract the person measuring would calculate Items 1 and 2 together from the measurement sheets and insert them into the Bill of Quantities: this was not a reasonably practicable proposition where some 3000 Bills of Quantities, and consequently a separate data processing unit (whether manual or mechanical) were necessary. In cases where it was considered that 'Extra Over' items would not apply to the majority of the measurements to be taken, such items were adopted and all the quoted examples could be seen on the specimen bill.

96. A suggestion that items for which the cubic unit rate varied by some $15 \%$ should be combined was unlikely to be acceptable to the Consulting Engineer or the Contractor. Surely, this was over-simplification and was without justification.

97. To the question raised by $\mathrm{Mr}$ Asit $\mathrm{K}$. Biswas the Authors replied that the standard of supervision was at least as high as that on any other normal civil engineering contract, and the remedial works required to the site works were certainly no greater than might be generally expected. This was, in itself, an achievement, taking 
CO-ORDINATION, MEASUREMENT OF CIVIL ENGINEERING AND BUILDING WORKS 123

into account the considerable additional supervisory difficulties emanating from the magnitude of the works and their speed of construction. The incident referred to related to a number of piles in the steel making plant. The matter was both discovered and rectified by the Contractor without cost to the Client or delay to the project. It was inevitable that external aid projects should be subjected to considerable political comment. 